\title{
Effect of Different Concentrations of Hypertonic Saline at Different Times on Protoscoleces of Hydatid Cyst Isolated From Liver and Lung
}

\author{
Karaciğer ve Akciğerden İzole Edilen Hidatid Kist Protoskoleksleri Üzerine Hipertonik \\ Tuzun Farklı Zaman ve Farklı Konsantrasyonlardaki Etkisi
}

\section{Khosrow Hazreti Tappeh', Ali Einshaei², Rahim Mahmudloo², Habib Mohammadzadeh1, Mansoor Tahermaram¹, Seyed Javad Mousavi}

${ }^{1}$ Department of Parasitology and Mycology, Urmia University of Medical Sciences, Urmia, Iran

${ }^{2}$ Department of Surgery, Urmia University of Medical Sciences, Urmia, Iran

\begin{abstract}
Objective: Most surgeons inject scoloidal materials into the cyst before or after its removal, since any contamination to normal sites will cause re-growth of the same cyst. The aim of this study was to determine the lethal effect of hypertonic saline at different doses and different times on protoscolexes of lung and liver.

Methods: The livers and lungs of killed animals with hydatid cyst disease were gathered from Urmia Industrial Abattoirs. They were transferred to the university parasitological lab immediately. The hydatid cyst fluid was aspirated with a $10 \mathrm{~mm}$ syringe and poured into a $15 \mathrm{cc}$ tubes. The movement of protoscoleces and staining with $0.1 \%$ eosin was the test to determine viability of protoscoleces. Those with color absorption were those which were not viable. Different concentrations of hypertonic saline were given at different time.

Results: The results showed that in $20 \%$ of hypertonic saline in the $4^{\text {th }}$ minute, $80 \%$ of protoscoleces were alive while in the $5^{\text {th }}$ minute $50 \%$ were alive, in the $7^{\text {th }}$ minute $20 \%$ and $8^{\text {th }}$ minute $5 \%$, $9^{\text {th }}$ minute all of them were dead. In the $10 \%$ concentration, at up to 9 minutes $50 \%$ were alive, in the $18^{\text {th }}$ minute $20 \%$ and in 30 minutes $10 \%$ of protoscoleces were alive. In the $5 \%$ concentration at up to 10 minutes $90 \%$ were alive while in the $22^{\text {nd }}$ minute $80 \%$ and in 30 minutes $70 \%$ of protoscoleces were alive.

Conclusion: When we inject $20 \%$ hypertonic saline into the cyst cavity there is aprobability that the cyst contaminates the bile duct and liver through the small hole we made. This material may cause widespread necrosis of the liver. We should use $10 \%$ hypertonic saline minimally for 45 minute before surgery and after cyst removal, since the hypertonic saline itself may cause injury to the biliary system. (Turkiye Parazitol Derg 2011; 35: 148-50)
\end{abstract}

Key Words: Hydatid cyst, hypertonic saline, Echinococcus granulosus

Received: 09.05.2011

Accepted: 20.07.2011

ÖZET

Amaç: Birçok cerrah hidatik kisti çıkarmadan önce veya sonra yeni bir kist gelişimine engel olmak amacıyla kistin içine skolisidal materyal enjekte etmektedir. Bu çalışmanın amacı, akciğer ve karaciğerdeki hidatik kistlerde bulunan protoskoleksler üzerine farklı zaman ve dozlarda uygulanan hipertonik tuzun öldürücü etkisini belirlemektir.

Yöntemler: Hidatik kist saptanan akciğer ve karaciğerler, Urmia şehri mezbahasındaki kesimlerden elde edilmiştir. Bu kistler hemen üniversite parazitoloji laboratuvarına getirilmiştir. Hidatik kist sıvısı 10 ml'lik şırınga ile aspire edilerek 15 ml'lik tüplere aktarılmıştır. Protoskolekslerin hareketleri gözlemlenmiş ve canlılıklarını belirlemek için \%0.1'lik eosin ile boyanmıştır. Boya alanlar cansız olarak değerlendirilmiştir. Hipertonik tuzun farklı konsantrasyonları farklı zamanlarda verilmiştir.

Bulgular: Hipertonik tuzun \%20 konsantrasyonunda; 4 dk' da protoskolekslerin \%80'inin, 5 dk' da \%50'sinin, 7 dk'da \%20'sinin, 8 dk'da \%5'inin canlı olduğu ve 9 dk'da hepsinin öldüğü belirlenmiştir. Hipertonik tuzun \%10'luk konsantrasyonunda ise 9 dk'ya kadar protoskolekslerin \%50'sinin canlı olduğu, 18 dk'da \%20'sinin, 30 dk'da \%10'unun canlı olduğu belirlenmiştir. \%5 konsantrasyonda ise 10 dk'ya kadar \%90'ının canlı olduğu ve 22. dk'da \%80'inin, 30 dk'da \%70'inin canlı olduğu gözlemlenmiştir.

Address for Correspondence / Yazışma Adresi: Dr. Rahim Mahmudloo, Department of Surgery, Urmia University of Medical Sciences, Urmia, Iran Phone: +984413654928 E-mail: mahmodlou@yahoo.com doi:10.5152/tpd.2011.37 
Sonuç: Hidatik kist boşluğunun içine \%20'lik hipertonik tuz enjekte edildiği zaman, kistin safra kanalı ve karaciğeri şıınnga tarafından açılan küçük delikten kontamine etme olasılığı bulunmaktadır. Bu materyal karaciğer nekrosisinin yayılımına sebep olabilir. Hipertonik tuzun kendisi de bilier sistemde hasara sebep olabileceğinden operasyondan en az 45 dk önce ve kist çıkarıldıktan sonra \%10'luk hipertonik tuz mutlaka kullanılmalıdır. (Turkiye Parazitol Derg 2011; 35: 148-50)

Anahtar Sözcükler: Hidatik kist, hipertonik tuz, Echinococcus granulosus

Geliş Tarihi: 09.05.2011 Kabul Tarihi: 20.07.2011

\section{INTRODUCTION}

Echinococcosis in humans and animals is an economic and public health concern in many parts of the world (1). The infection is most prevalent in sheep- and cattle-raising regions like Australia, South America, the Middle East, South Africa, Eastern Europe, and the Mediterranean region (2). Cystic hydatid disease affects mainly the liver (50-70\% of all cysts) but can also develop in lung (20-30\%) and, less frequently, in spleen, kidney, bone, brain, and other organs (3).

There are currently three treatment options for hydatid disease of the liver: surgery, which remains the most efficient treatment, percutaneous aspiration, and medical treatment (4). Surgery is still the preferred method of treatment, although it increases the risk of intraoperative spillage of scolices.

Currently, many scolicidal agents, which have some complications of their own, have been used for inactivation of the cyst content (5). Various scolicidal solutions have been used for surgical and precutaneous approaches. 1, 2 Caustic sclerosing cholangitis is a dreadful complication after surgical treat- hypertonic saline is one of the most common scolicidal agents in the world. The rationale for its use is simply that it affects a sufficiently strong osmotic gradient across the outer cuticular membrane of the scolex to cause lysis.

The objective of this study is to determine the scolocidal effect of hypertonic saline in different concentrations using different exposure times.

\section{METHOD}

Protoscolices of Echinococcus granulosus were obtained from the infected livers and lung of sheep slaughtered at Urmia city in Northwest of Iran. The hydatid fluid was transferred into glass cylinders and left to set for $30 \mathrm{~min}$.

The protoscolices settled down at the bottom of the cylinders. The supernatant was removed and the yielded protoscolices were washed two times with normal saline. The viability of the protoscolexes was confirmed by their motility under a light microscope and protoscolexes stained with $0.1 \%$ eosin were examined under at room temperature. Each protoscolex that did not take the dye in was accepted as potentially viable.

The live protoscolexes were finally transferred into a dark container containing normal saline solution and stored at $4{ }^{\circ} \mathrm{C}$ for further use.

The mean number of protoscolexes in the cyst fluid obtained from different cysts in different periods was found as 1000 protoscolexes $/ \mathrm{mm}^{3}$ and fourteen samples of $0.5 \mathrm{cc}$ sediment were obtained. Various concentrations of $1 \mathrm{cc}$ sodium chloride solutions were added to each sediment (1\%, $2 \%, 3 \%, 4 \%, 5 \%, 6 \%$,
$7 \%, 8 \%, 9 \%, 10 \%, 20 \%$ respectively). We waited $1,2,3,4,5,6,7$, $8,9,10, \ldots . . .29$, and 30 minutes for each concentration, following which the upper portions of the solutions were removed. The remaining settled protoscolices were then washed in normal saline and after staining, examined for viability.

\section{RESULTS}

The viability ratios of protoscoleces after exposure to different concentrations of the sodium chloride in the different times are shown in Table 1.

Hypertonic salin $20 \%$ had a strong scolicidal effect, because killed all of the protoscoleces at the end of 9 minutes. The hypertonic salin $10 \%$ killed ninety percent of the protoscoleces at 30 minute (Table 1).

\section{DISCUSSION}

Surgery is still the treatment that has the potential to remove Echinococcus granulosus cysts and lead to complete cure. The main principles of surgery are the prevention of spillage of the scolices by a suitable placement of swabs soaked with scolicidal agents (6). If the liquid content of the cyst penetrate to neighbor organs as the surgeon is trying to expel and/or unload it, there will be always a risk of creation of new cysts and recurrence of the disorder (7). So to prevent (or at least decrement of probability of) this phenomenon, scolecidal agents were injected to cyst during surgery by surgeon (8). Various materials were already used as scolecidal agents (9). The use of protoscolicidal substances for intraoperative killing of protoscoleces is questionable, as there is no ideal agent that is both effective and safe (10). Hypertonic saline has been used as a scolicidal in various concentrations $3-30 \%$ (11). It is known that high concentration saline can cause sclerosing cholangitis and bile duct strictures.

Avoiding spillage of the cyst contents and the use of effective scolicidal agents are essential to lower the recurrence rate (12). Various scolicidal agents such as $95 \%$ alcohol, povidone iodine, hypertonic saline, hydrogen peroxide, 5\% formalin, silver nitrate, cetrimide, and albendazole have been evaluated for scolicidal effects $(6,12)$. Deliberation on the side effects of some materials like Silver Nitrate, Formalin, Hypertonic Saline, and Cetrimide-C on 24 Guinea pigs was cited in an article published in 1991. These effects were scrutinized in two phases: first phase at the first week and the other after five months. Damages caused by formalin were $45 \%$ in first week and $40 \%$ after five months. Cetrimide-C made $11 \%$ of damage in first week and $18 \%$ after five months. Silver Nitrate caused a damage of $4 \%$ in first week and $7 \%$ after five months, and hypertonic Saline caused $9 \%$ and $4 \%$ damages in first week and after five months, respectively (13). A good scolecidal agent might do its lytic effect in lowest consternations, shortest time, and with the least side effects. 
Table 1. Scolicidal effects of different concentrations of hypertonic saline and exposure times

\begin{tabular}{|c|c|c|c|c|c|c|c|c|c|c|c|c|c|c|}
\hline & & \multicolumn{13}{|c|}{ Time (Minute) } \\
\hline & $\begin{array}{l}\text { Scolocidal } \\
\text { agents }\end{array}$ & 2 & 4 & 6 & 8 & 10 & 12 & 14 & 16 & 18 & 20 & 24 & 26 & 30 \\
\hline \multirow{12}{*}{ 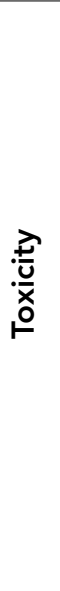 } & Salin0.9\% & 98 & 98 & 98 & 98 & 98 & 96 & 96 & 96 & 95 & 90 & 90 & 90 & 95 \\
\hline & Salin1\% & 98 & 98 & 98 & 98 & 98 & 96 & 96 & 96 & 95 & 90 & 90 & 90 & 95 \\
\hline & Salin2\% & 98 & 98 & 98 & 98 & 98 & 96 & 96 & 96 & 95 & 90 & 90 & 90 & 95 \\
\hline & Salin3\% & 98 & 98 & 98 & 98 & 75 & 96 & 96 & 96 & 95 & 90 & 90 & 90 & 95 \\
\hline & Salin4\% & 95 & 90 & 90 & 90 & 90 & 90 & 90 & 90 & 95 & 90 & 80 & 80 & 80 \\
\hline & Salin5\% & 98 & 90 & 90 & 90 & 90 & 90 & 90 & 90 & 90 & 90 & 70 & 70 & 70 \\
\hline & Salin6\% & 85 & 85 & 85 & 85 & 85 & 85 & 85 & 80 & 80 & 80 & 80 & 80 & 80 \\
\hline & Salin7\% & 90 & 90 & 90 & 90 & 90 & 80 & 80 & 80 & 80 & 80 & 80 & 50 & 50 \\
\hline & Salin8\% & 80 & 80 & 70 & 70 & 70 & 70 & 70 & 70 & 70 & 70 & 40 & 40 & 40 \\
\hline & Salin9\% & 90 & 90 & 60 & 60 & 60 & 40 & 40 & 40 & 30 & 30 & 30 & 30 & 20 \\
\hline & Salin10\% & 90 & 80 & 40 & 40 & 40 & 20 & 20 & 20 & 20 & 10 & 10 & 10 & 10 \\
\hline & Salin20\% & 80 & 80 & 20 & 5 & 0 & 0 & 0 & 0 & 0 & 0 & 0 & 0 & 0 \\
\hline
\end{tabular}

Injection of a scolecidal agent into a cyst without unloading its contents could cause its dilution, as lytic effect of a scolecidal agent is relevant to its concentration and not to contact time.

We found different concentrations of hypertonic saline, for example $1 \%, 2 \%, 3 \%, 4 \%$ and $5 \%$ ineffective even at the end of 30 minutes. Saidi and Kayaalp demonstrated that $5 \%$ saline was ineffective in 60 minutes. Ten percent saline was effective at the end of 75 minutes (11), but we found $10 \%$ saline to be effective in 30 minutes. Another study had shown that $20 \%$ saline was effective in 5 minutes (14), but we shown that $20 \%$ saline was effective in 9 minutes.

According to the results of present study, hypertonic saline with concentration $20 \%$ killed all protoscoleces of hydatid cyst at the end of 9 minutes. Hypertonic saline did not cause any systemic side effects when it was applied intraperitoneally.

\section{Acknowledgements}

We would like to thank Vice Research Chancellor of Urmia University of Medical Sciences for funding this research.

\section{Conflict of Interest}

No confl ict of interest was declared by the authors.

\section{REFERENCES}

1. Lahmar S, Lahmar S, Boufana B, Bradshaw H, Craig PS. Screening for Echinococcus granulosus in dogs: comparison between arecoline purgation, coproELISA and coproPCR with necropsy in pre-patent infection. Veterinary Parasitology 2007; 144: 287-92. [CrossRef]

2. Zulfikaroglu B, Koc M, Ozalp N, Ozmen MM. A rare primary location of echinococcal disease: report of a case. Upsala Journal of Medical Sciences 2005; 110: 167-71. [CrossRef]

3. Ammann R, Eckert J. Cestodes: Echinococcus. Gastroenterol Clin North Am 1996; 25: 655-89. [CrossRef]
4. Adas G, Arikan S, Kemik O, Oner A, Sahip N, Karatepe O. Use of albendazole sulfoxide, albendazole sulfone and combined solutions as scolicidal agents on hydatid cysts (in vitro study). World J Gastroenterol 2009; 15: 112-6. [CrossRef]

5. McManus DP, Zhang W, Li J, Bartley PB. Echinococcosis. Lancet 2003; 362: 1295-304. [CrossRef]

6. Sahin M, Eryilmaz R, Bulbuloglu E. The effect of scolicidal agents on liver and biliary tree (experimental study). J Invest Surg 2004; 17: 323-6.

7. Barros JIU. Hydatid disease of the liver. AM J Surg 1987; 135: 597600.

8. Hazrati tappe $\mathrm{KH}$, Mousavi S J, Barazesh A. In vitro study of scolocidal effect of Methylen Blue in Hydatid cyst. Iranian South Medical Journal 2010; 13: 123-8.

9. Eyüpoğlu $B$, Doğanay $M$, Reis $E$, et al. The effects of scolocidal agents on hepatopancreaticobiliary system "An experimenal study". Turkish J Gastroenterol 1999; 10: 280-6.

10. Yetim I, Erzurumlu K, Hokelek M, Baris S, Dervisoglu A, Polat C, et al. Results of alcohol and albendazole injections in hepatic hydatosis: Experimental study. J Gastroenterol Hepatol 2005; 20: 1442-7. [CrossRef]

11. Kayaalp C, Balkan M, Aydin C, Ozgurtas T, Tanyuksel M, Kirimlioglu $\checkmark$, et al. Hypertonic saline in Hydatid Disease. The world journal of surgery 2001; 25: 975- 9. [CrossRef]

12. Topcu O, Sumer Z, Tuncer E, Aydin C, Koyuncu A. Efficacy of chlorhexidine gluconate during surgery for hydatid cyst. World J Surg 2009; 33: 1274-80. [CrossRef]

13. Besim H, Karayalçin K, Hamamci O, Güngör C, Korkmaz A Scolicidal agents in hydatid cyst surgery. HPB Surgery 1998; 10: 347-51. [CrossRef]

14. Karayalçin K, Besim H, Sonisik M, Erverdi N, Korkmaz A, Aras N. Effect of hypertonic saline and alcohol on viability of daughter cysts in hepatic hydatid disease. European Journal of Surgery 1999; 165: 1043-4. 